\title{
IS IT BAD TO CONTROL TOO MUCH? THE EFFECT OF THE REGULATORY FOCUS ON THE ESTIMATION OF SHORT TIME INTERVALS UNDER COMPETITIVE PRESSURE
}

\author{
V.A. GERSHKOVICH ${ }^{\mathrm{a}}$, N.V. MOROSHKINA ${ }^{\mathrm{a}}$, A.K. KULIEVA ${ }^{\mathrm{a}}$
}

${ }^{a}$ Saint Petersburg State University, 7/9 Universitetskaya emb., Saint Petersburg, 199034, Russian Federation

\begin{abstract}
Choking under pressure is the phenomenon known in sport as errors in the automated motor skill execution that appear under circumstances that increase the importance of good or improved performance (Baumeister, 1984). Several theories claim that the reason for this phenomenon lies in control reinvestment, which provokes skill de-automatization. According to our hypothesis, control reinvestment appears due to fear of making a mistake, because an attempt to check "if the mistake is made or not" paradoxically provokes a mistake (Allakhverdov, 2000; Wegner, 1994). In our study we analyzed the influence of two factors: the "value" factor (regular vs valuable trials); and the "frame of the task" factor (bonus vs penalty). Participants played a computer game "Virtual Golf", competing with each other. In a golf-like virtual scenario, a player had to learn to putt the ball to a hole displayed on the screen by pressing and holding a key for a certain period $(2,4,6,8 \mathrm{sec})$. The value of the target was manipulated during the competition session. In addition, one group was penalized for failing to hit the valuable target, whereas the other group received extra rewards for a hit. The generalized data of the experiment is in line with the theory of control reinvestment, as well as the idea that excessive control adversely affects performance of simple automated tasks. We observed choking under pressure when participants were putting balls in the closest targets $(2 \mathrm{sec})$ : participants made more errors putting the ball to valuable targets than to regular ones. The influence of task frame on the time taken for preparation for the trials was discovered: the "penalty" group prepared longer. We also found out that when more time was taken preparing for the shot, more errors were made.
\end{abstract}

Keywords: choking under pressure, competitive pressure, reinvestment of control, estimation of time intervals, regulatory focus, task frame, penalty, reward, errors.

\section{Introduction}

Choking under pressure is the phenomenon known in sport as errors in the automated motor skill execution that appear under circumstances that increase the importance of good or improved performance (Baumeister, 1984). In sport, this phenomenon is often related to emotional pressure caused by competition. There is

This work was supported by RFBR grant \#16-06-00376. 
no single view on mechanisms that lead to a failure in skill execution during highpressure situations.

Traditionally, in Russian sport psychology this problem is seen as the problem of sportsmen's performance reliability in the instances of competitive pressure (Plakhtienko \& Bludov, 1983; Malinina, 2006). Even though sometimes there can be improvement of performance during competition, impairment of performance appears more often, and worry, caused by competition, provokes deterioration in skill execution (Vainstein, 1981; Kochetkova, 2000; Medvedev et al., 1973). According to Safonov (2018) the discrepancy between real and desirable results provokes the cognitive dissonance in performance regulation. And only if sportsmen retain the ability to control the situation, can they correct their actions. The type of achievement motivation is an important factor here, because it mediates the engagement and direction of attention to the different aspects of performance regulation (Ibid.).

In foreign psychology several theories explaining the role of attention and cognitive control in choking under pressure have also been developed. The processing efficiency theory (Eysenck \& Calvo, 1992) states, firstly, that errors are caused by distraction of attentional resources toward worry about the result; and, secondly, that this reduction in available attentional resources may be compensated for by an increased effort. This theory postulates that the increase of control is not the reason for errors, but reacts to detrimental effects of anxiety on performance and can apply additional resources (e.g. lengthen the processing time) and/or different strategies to compensate for the negative effect (Eysenck \& Calvo, 1992; see also Wilson, 2008 for review). Contrariwise, the explicit monitoring theory (reinvestment theory) states that choking under pressure decrements occur due to refocusing extra attention and control to the skill components (Beilock, Carr, MacMahon, \& Starkes, 2002; Masters, 1992); thus disruptive effects occur when a person tries to consciously control (apply explicit rules to) their movements. These accounts are built on the theory of stages of skill learning (Fitts \& Posner, 1967). This idea is very similar to the one outlined by Bernstein (Bernstein, 1966), who described the concept of de-automatization of movements due to the conscious attention allocation to lower levels of movement coordination. Thus, it seems reasonable to pose the following question: why does reinvestment of control provoke errors in a competitive situation? Several theories claim that the reason for this phenomenon lies in an individual's desire not to make a mistake, which in turn evokes ironic control assessing if the mistake is made or not, which, in turn, paradoxically provokes a mistake (Allakhverdov, 2000; Wegner, 1994). Hence the higher the desire not to make a mistake, the greater the possibility that it will be made.

Thus, if the frame of a situation emphasizes the high cost of errors it influence on the strategy of goal achievement (Moroshkina, Gershkovich, Ivanchei, \& Morozov, 2012; Gershkovich at el., 2013; Gershkovich \& Urikh, 2017), changing the strategy of goal achievement. This idea is based on D. Kahneman and A. Tversky prospect theory (Tversky \& Kahneman, 1979), which states that values of gain and losses are not equivalent. Also, according to the regulatory focus theory (Higgins, 1997) goal-directed behavior is regulated by two different motivational 
systems (self-regulation strategic systems) - promotion focus and prevention focus, which can be situationally induced (Higgins, 1998; Shah \& Higgins, 2001). Prevention regulatory focus strives for security and non-losses, while the promotion focus strives for positive end-states and gains. The reward structure can be seen as one of the factors that evoke a certain regulation focus: the promotion focus can be situationally induced by stressing possible rewards; the prevention focus can be induced by stressing possible penalties.

In our previous research (Moroshkina et al., 2012; Gershkovich et al., 2013) participants had to shoot at moving targets in a simple computer-based game. We increased the value of every fifth target and manipulated the frame of the situation: Group one received five more points for a hit, while Group two was penalized by minus five points for a miss on that particular target. The task framing effect on sensorimotor performance was demonstrated. Though no difference in accuracy between bonus/penalty groups was found while shooting at the high-value targets, preparation time for the high-value (5-th) target in the penalty group was significantly longer, thus indicating a change in the control strategy.

The aim of the present study was to replicate the results within a different cognitive task based on short-time intervals estimation. This cognitive task was used because of several reasons. It is considered that choking is a decline in skill performance, which is, supposedly, due to reinvestment of control. However, there is data that demonstrates that a switch from automatic to controlled actions changes the subjective estimation of temporal duration (Herai \& Mogi, 2014; Lewis \& Miall, 2003). Hence, if the hypothesis of control reinvestment is true, we observe a prominent effect of choking in tasks associated with time interval estimation. We have chosen the "Virtual Golf" task (Gershkovich \& Urikh, 2017). In a golf-like virtual scenario, a player had to putt the ball to a hole displayed on a screen by pressing and holding a key for a certain period of time (the subjective estimation of a time interval). We have shown that the execution of such a task is prone to competitive pressure.

Therefore, in the present paper we tested the following hypotheses:

1. Participants will make more errors in the situation of competitive pressure, shooting at valuable targets than for regular ones, because they will increase control over desire not to make an error.

2. We will observe an effect of task frame: the penalty instruction would induce prevention focus, which in turn would evoke safety-oriented strategy (carefulness, striving for non-losses), causing choking and increased probability of error.

3. The increase of control will manifest in the increase of time, taken for preparation for shooting. Thus, we assume that preparation for shooting at valuable targets will take more time than for regular ones, and preparation for shooting within the penalty task frame will take more time than within the reward task frame, but performance will decrease.

\section{Method}

Participants and design. A total of 30 participants (27 females) aged 18 to 23 $(\mathrm{M}=19.4, \mathrm{SD}=1.2)$ took part voluntarily in the study. All participants were 
undergraduate-level students of Saint Petersburg State University. All participants had normal or corrected to normal visual acuity. Participants were motivated to win a monetary reward in a competition during the experiment. In addition, each participant received a candy bar after the experiment. Upon arrival, each participant signed the informed consent form. Participants were assigned to two experimental groups (penalty vs bonus) with matched-subjects design, based on Prevention Scale scores for Regulatory Focus Questionnaire (Higgins et al., 2001, Russian adaptation Gershkovich, Moroshkina, Kulieva, \& Nasledov, 2019). A total of 16 participants (14 females), aged 18 to $23(\mathrm{M}=19.4, \mathrm{SD}=1.15)$, M prevention focus scores $=19.71, \mathrm{SD}=2.84$ took part in the penalty group, and 14 participants (13 females), aged 18 to $23(\mathrm{M}=19.3, \mathrm{SD}=0.73)$, $\mathrm{M}$ prevention focus scores $=$ $18.75, \mathrm{SD}=3.41)$ took part in the bonus group.

We varied two independent variables: the value of the target (in within-subject manner) and the frame of the task (in between-subject manner). We also controlled for the task complexity: there were four different distances to targets.

\section{Method}

The experiment was organized as a computer game competition. The "Virtual Golf" scenario was used (Gershkovich \& Urikh, 2017). The screen showed two objects: a ball and a target located on horizontal line. The location of the ball was constant; the target changed its position along horizontal line. The four positions of target were used: 4, 8, 12 or $16 \mathrm{~cm}$ from the ball.

The task was to put the ball in a target. In order to do this the participant had to press and hold the spacebar; the longer the player holds the key, the further the ball goes (the speed of the ball is $2 \mathrm{~cm}$ per second). There was no visible scale on the screen and the player had to subjectively estimate time intervals. Four different time intervals were used in the game -2 seconds, 4 seconds, 6 seconds and 8 seconds, respectively to the distance. Hitting the target occurs if the ball is completely covered by the target (the participant should hold the spacebar for 2, 4, 6 or 8 seconds $+/-225 \mathrm{msec}$ ); then the target becomes green. If any part of the ball is outside the target, the result is a miss and the target becomes red. After each trial, feedback appeared in the screen - a message indicating the size of error in conditional "meters" (1 conditional "meter" is $1 \mathrm{~cm}$ ), its direction ("+" - overshoot, "-" undershoot) or indicating a correct hit. Participants played wearing headphones. Hits and misses in the game were followed by the sound of applause or a disapproving rumble, respectively.

The value of the target was manipulated during the competition session. There were two types of targets - regular ones (where the participant was awarded with 1 point for each correct hit and misses were not penalized by any points) and valuable ones (where the participant was either awarded with 5 points for each correct hit and misses were not penalized by any points (the so-called "bonus" group); or the participant was awarded with 1 point for each correct hit, but they were penalized for misses by the subtraction of 5 points (the so-called "penalty" group)). 
The pressure situation was simulated by announcing a competition with other participants. It was announced that there would be three prizes for each group for the first place (3,000 rubles), for the second place (1,000 rubles) and for the third place (500 rubles).

\section{Procedure}

A strategy for non-losses was an important parameter for our research, so we controlled for individual Prevention Regulatory Focus with the help of the Regulatory Focus Questionnaire, developed by Higgins et al (Higgins et al., 2001). We used a Russian adaptation of the Questionnaire (Gershkovich et al., 2019). In order to ensure that filling in the questionnaire did not influence the experimental procedure, we had tested the participants one week before the main part of the experiment.

The experiment was conducted in groups. Upon arrival at the laboratory, the participants were told that they would compete with each other, and the winners would receive a prize. They read and signed the informed consent forms, though the information about differences in target values during competition was not revealed in the form and was disclosed only after the experiment. Then the participants took their places and all of them started the experiment in parallel. The participants could not use any clock or watches.

Participants read the instruction outlining the rules of the "Virtual Golf" game. They were informed that there would be 2, 4, 6 or 8 sec time intervals. Two short training sessions were used to familiarize the participants with the relationship between the distance to target and the time interval.

The 1st training session (warm-up) consisted of 8 trials (two for each distance). The 2nd training session consisted of 20 trials ( 5 for each distance presented in successive order). Then the competition was announced. It consisted of 200 trials (160 regular ones and 40 valuable ones) presented in a pre-defined order to control the distance to targets (each distance appeared 50 times). Two valuable targets would never appear successively. The regular target was colored in violet, while the valuable one - in golden. The participant could press the spacebar immediately after the ball and the target appeared in the screen. After each shot a feedback message (hit/miss) and scores were presented and the participant had to press "OK" to proceed. The experimental task was self-paced and took approximately 35 min (32 to $37 \mathrm{~min})$.

\section{Apparatus}

For the experiment, 30 equal computers and monitors in St. Petersburg State University computer class were used. Monitor parameters - size 22", resolution $1680 \times 1050$, update frequency $60 \mathrm{~Hz}$. 


\section{Measures}

As dependent variables we measured: the proportion of hits (the number of correct hits divided by overall number of shots); error deviation from the target center in conditional "meters"); time spent for preparation for each shot (in seconds).

\section{Results}

\section{Training}

General performance: hit/miss. We found no significant effect of group in the number of hits and misses during the training stage (bonus group: $\mathrm{M}$ (hits) $=0.4$; penalty group: $\mathrm{M}$ (hits) $=0.43 ; \chi^{2}(1)=0.74, p=.39$ ). ANOVA RM did not show significant effect of group on the absolute error size $(\mathrm{F}(1,28)=.90, p=.35)$, but showed significant effect of target distance $(\mathrm{F}(3,84)=15.47, p<.001)$ between "2 sec" targets $(\mathrm{M}=0.74 ; \mathrm{SD}=0.84)$, " $4 \mathrm{sec"}(\mathrm{M}=0.87 ; \mathrm{SD}=0.87)$, " $6 \mathrm{sec"}(\mathrm{M}=0.97$; $\mathrm{SD}=0.80)$ and "8 sec" targets $(\mathrm{M}=1.52 ; \mathrm{SD}=1.43)$. We can conclude that the groups did not differ in terms of performance before the experimental manipulation.

Time taken for preparation to shoots. ANOVA did not show significant main effect of group $(\mathrm{F}(1,28)=0.00, p=.97)$ on preparation time for each trial.

\section{Competition}

General performance: hit/miss. The proportion of hits for each target type was counted (by the factors of distance and value) and aggregated for each participant. ANOVA RM was conducted, with the factors being: target distance (2 sec, $4 \mathrm{sec}$, $6 \mathrm{sec}, 8 \mathrm{sec}$ ), target value (valuable $v s$ regular) and group (bonus $v s$ penalty). The significant impact of the factors: target distance $(\mathrm{F}(3,84)=29.83, p<.001, \eta=.26)$ (see Table 1) and the interaction of target distance and target value $(\mathrm{F}(3,84)=3.25$, $p=.026, \eta=.02$ ) was demonstrated.

The difference between the groups did not reach significance $(\mathrm{F}(1,28)=3.92$, $p=.06$; bonus: $\mathrm{M}=0.56, \mathrm{SD}=0.22$; penalty: $\mathrm{M}=0.64, \mathrm{SD}=0.19$; see Figure 1).

Thus, in terms of errors, the more distant the target, the more complicated is the task for participants. Also, a significant interaction effect of target value and distance

Table 1

Proportion of Hits Dependent on the Target Distance

\begin{tabular}{|c|c|}
\hline Target distance & Proportion of hits \\
\hline $2 \mathrm{sec}$ & $0.75(\mathrm{SD}=0.17)$ \\
\hline $4 \mathrm{sec}$ & $0.64(\mathrm{SD}=0.19)$ \\
\hline $6 \mathrm{sec}$ & $0.55(\mathrm{SD}=0.19)$ \\
\hline $8 \mathrm{sec}$ & $0.48(\mathrm{SD}=0.18)$ \\
\hline
\end{tabular}


Mean Proportion of Hits for the Bonus and Penalty Groups for Regular and Valuable Target Types and Different Distance Trials

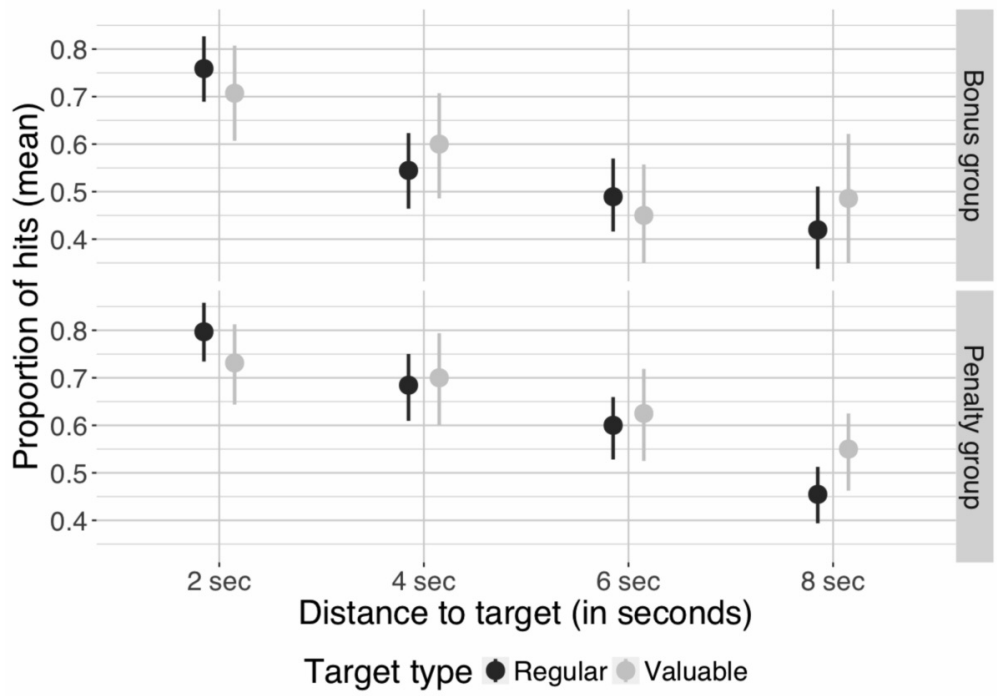

to target was demonstrated: participants had more misses for valuable targets than for regular ones when shooting at the closest targets, and the opposite for the most distant ones in both groups. Contrary to our hypothesis, the penalty group was slightly more efficient in general than the bonus group.

General performance: error deviation from targets center. We aggregated error data (in conditional "meters") from target center for each participant, excluding accurate hits (error $=0$ ). $2 \%$ of data points over 3 SD's below and above each participant's mean were excluded from the database.

Mean error deviation aggregated for each target distance were submitted to ANOVA RM, with factors being target distance, target value and group. This revealed a significant main effect of group $(\mathrm{F}(1,28)=4.48, p<.050,=.07$; bonus: $\mathrm{M}=0.67, \mathrm{SD}=0.61$; penalty: $\mathrm{M}=0.56, \mathrm{SD}=0.53)$, target distance $(\mathrm{F}(3,84)=36.00$, $p<.001, \eta=.28$; see Table 2$)$ and their interaction $(\mathrm{F}(3,84)=2.79, p<.05, \eta=.02)$.

Table 2

Mean Error Deviation Dependent on the Target Distance

\begin{tabular}{|c|c|}
\hline Target distance & $\begin{array}{c}\text { Mean error deviation from the target center } \\
\text { (in conditional “meters") }\end{array}$ \\
\hline $2 \mathrm{sec}$ & $0.40(\mathrm{SD}=0.38)$ \\
\hline $4 \mathrm{sec}$ & $0.55(\mathrm{SD}=0.51)$ \\
\hline $6 \mathrm{sec}$ & $0.68(\mathrm{SD}=0.61)$ \\
\hline $8 \mathrm{sec}$ & $0.80(\mathrm{SD}=0.67)$ \\
\hline
\end{tabular}


Also a significant interaction of target distance and target value $(\mathrm{F}(3,84)=3.86$, $p<.01, \eta=.02$ ) was revealed (Figure 2).

Using such data as error deviation from the target center, we demonstrated that the penalty group was more accurate than the bonus group. In addition, the previously described result was confirmed: for the closest targets participants were less accurate shooting at valuable targets than for regular ones, and the opposite for the most distant ones in both groups.

Time taken for preparation. We analyzed the time each participant took to start pressing a button after the ball and the target appeared on the screen. Data were aggregated for each participant, $2 \%$ of data points over 3 SD's below and above each participant's mean were excluded.

ANOVA RM $(2 \times 2)$ with such factors as group and target value was conducted. Significant impact of the following factors: group $(\mathrm{F}(1,28)=7.27, p<.05, \eta=.19$; bonus: $\mathrm{M}=0.95, \mathrm{SD}=0.60$; penalty: $\mathrm{M}=1.29, \mathrm{SD}=0.75)$ and target value $(\mathrm{F}(1$, $28)=42.22, p<.001, \eta=0.10$; regular: $\mathrm{M}=1.08, \mathrm{SD}=0.65$; valuable: $\mathrm{M}=1.33$, $\mathrm{SD}=0.85$ ) was revealed. It took more time for the participants to prepare for valuable targets than for regular ones. Participants from the penalty group prepared longer than participants from the bonus group (Figure 3 ).

Analysis of the relation between time taken for preparation (time delay) and the subsequent proportion of hits and misses. We found out that preparation for shooting at valuable targets took more time than for regular ones, and preparation for shooting within the penalty task frame took more time than within the reward task frame. However, we also assumed that a longer preparation would negatively relate to performance. To test this hypothesis, we conducted the following analysis: data

Figure 2

Mean Error Deviation from Targets Center for the Bonus and Penalty Groups for Regular and Valuable Target Types and Different Distance Trials (accurate hits, with error size $=0$ were excluded from the analyses. Trials with error size larger than $\mathrm{M} \pm 3 \mathrm{SD}$ for each participant were excluded)

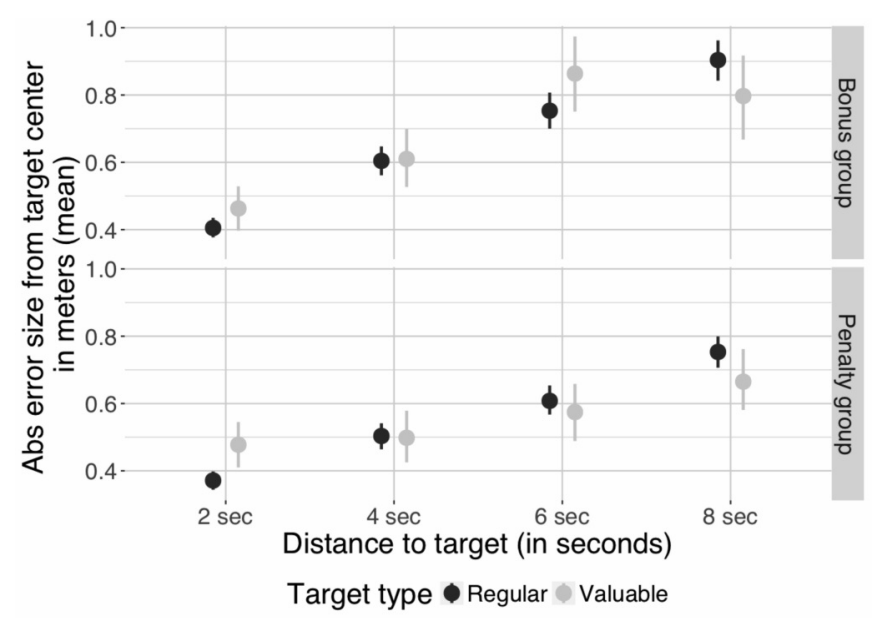


was aggregated for each participant separately for each target distance and separately for subsequent hits and misses, $1.25 \%$ of data points over 3 SD's below and above each participant's mean were excluded.

ANOVA RM $(2 \times 2 \times 4)$ with such factors as group, performance (hit/miss), and target distance was conducted. Significant impact of the following factors: group $(\mathrm{F}(1,28)=10.39, p=.003, \eta=0.203)$, performance $(\mathrm{F}(1,28)=9.82, p=.004$, $\eta=0.021$ ) (see Figure 4), and an interaction of performance and target distance $(\mathrm{F}(3,84)=3.87, p=.012, \eta=0.019)$ (see Figure 5 ) was revealed. It took more time for the penalty group to prepare for a shot $(\mathrm{M}=1.29, \mathrm{SD}=0.75)$, than for the

Mean Preparation Time before Shooting for the Bonus and Penalty Groups for Regular and Valuable Targets Types

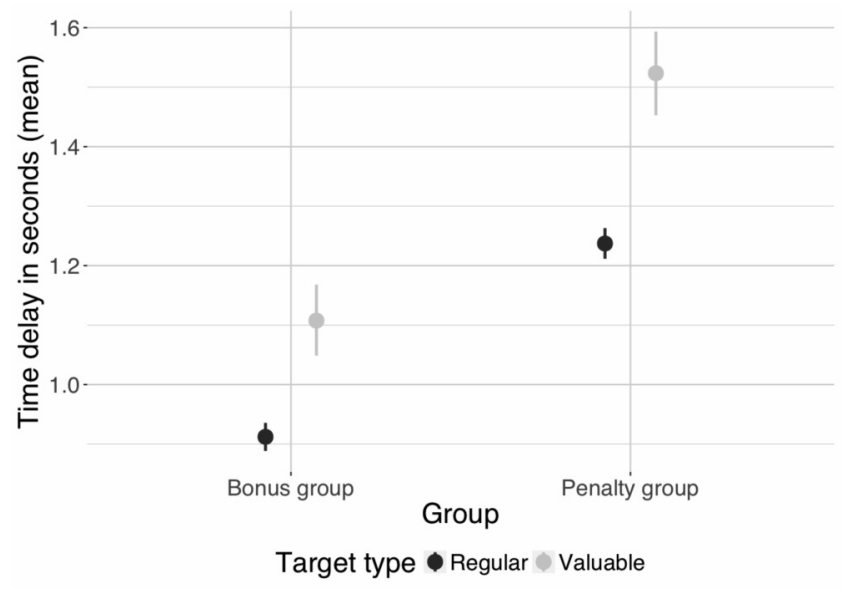

Figure 4

Mean Preparation Time before Shooting for the Bonus and Penalty Groups for Regular and Valuable Targets Types

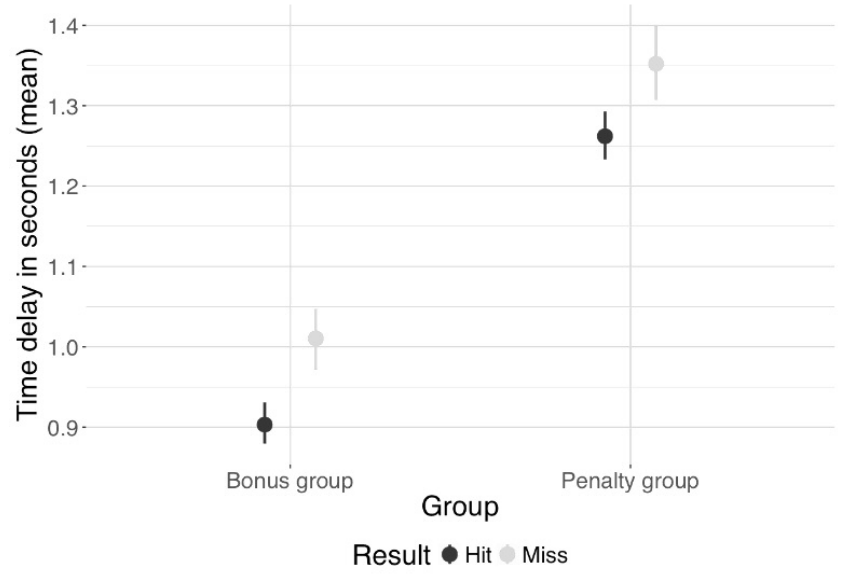




\section{Mean Preparation Time before Shooting for the Bonus and Penalty Groups with Regard to the Subsequent Performance Result (Hit or Miss) and Targets Distance}

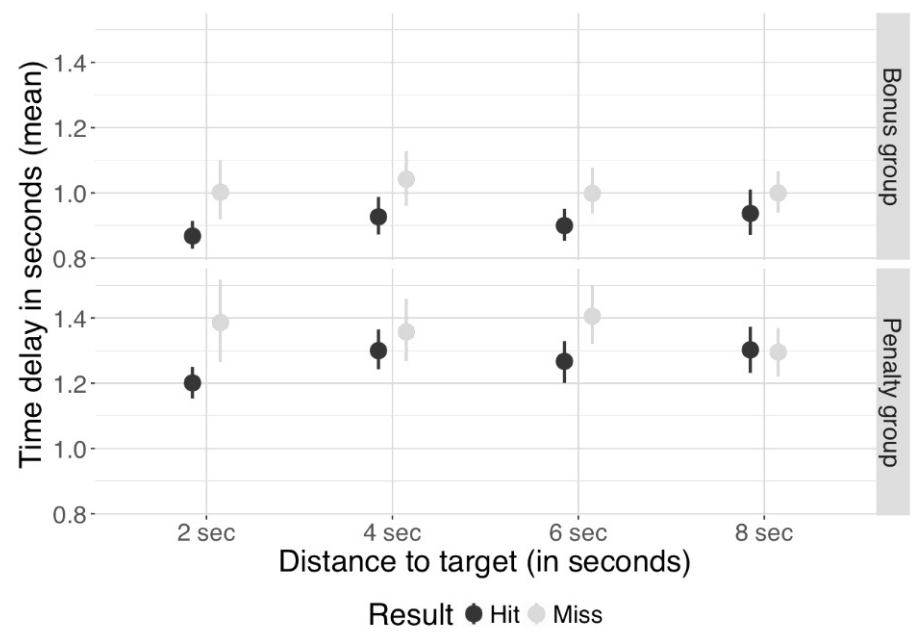

bonus group $(\mathrm{M}=0.95, \mathrm{SD}=0.60)$. In general, it took more time for the participants to prepare before miss $(\mathrm{M}=1.10, \mathrm{SD}=0.66)$ than hit $(\mathrm{M}=1.17, \mathrm{SD}=0.76)$. This effect is especially significant for the closest targets that in turn can cause differences in the overall means.

\section{Discussion}

We did not find any significant difference in performance between trials with valuable and regular targets. However, a significant interaction effect of target value and distance to target was demonstrated: participants made more mistakes for valuable targets than for regular ones when shooting at the closest targets, and the opposite for the most distant ones.

In other words, we observed choking under pressure when participants were performing simple tasks (short distances). The increased value of the trial outcome led to a deterioration in performance in both experimental groups. When participants performed a more complex task, the increased value of the outcome, on the contrary, led to improved performance. In our previous studies (Moroshkina et al., 2012; Gershkovich et al., 2013) we did not control for the task difficulty and the task was rather complex for the participants. Our current results are in line with the view suggested by S. Beilock and T. Carr (Beilock \& Carr, 2001), where negative influence of control reinvestment on task execution becomes crucial for tasks that are proceduralized and run largely unattended. In addition, according to regulatory focus theory, choking should be observed in easy tasks (where the base rate of hitting the goal is high). According to this theory, it is more of a failure to miss in an easy situation than in a difficult one, because it is subjectively perceived as 
"missing the opportunity" and an obligation to score a goal, and hence evokes prevention focus (Unkelbach, Plessner, \& Memmert, 2009).

We might nevertheless mention that our results are valid only for the female sample. It is still unclear if there are gender differences in the link between pressure and performance, and especially there is not much evidence for gender differences in responding to competitive pressure. For example, Gneezy, Niederle and Rustichini (2003) demonstrated that in competitive pressure men's performance increased, but not women's. But this effect was stronger when women have to compete against men than in women's competitive environments. On the other hand, Ariely et al. (2009) demonstrated that monetary rewards decreased performance, but they did not observe gender differences. Several studies analyzed professional sport data (tennis), searching for gender differences. Results were also controversial. In one study it was observed that although women show a drop in performance in crucial stages of competition, this drop was smaller than that of men (CohenZada, Krumer, Rosenboim, \& Shapir, 2017), whereas another study (De Paola \& Scoppa, 2017) suggested that women are more discouraged in a pressure situation, when receiving negative feedback at the beginning. In our study we observed the negative effect of control reinvestment on simple task execution within women.

This generalized data is in line with the theory of control reinvestment, as well as the idea that excessive control adversely affects performance of simple automated tasks. The main factor in our research was the value of the target, i.e. the impact of the possible outcome on the overall competition result. In this case, we suppose, participants reinvest control during task execution, which harms performance in simple trials.

In line with our hypothesis, the penalty group took longer to prepare before the shot; this result is the evidence for increased vigilance and control. In addition, participants in both groups prepared longer before shooting the valuable targets. Thus, longer time taken for preparation for valuable targets can be seen as a manifestation of reinvestment of control for error prevention. However, this extra control does not help to prevent errors. On the contrary, the more time that is taken preparing for a shot, the greater is the possibility to err. Moreover, it is especially so for the shortest distance targets.

Contrary to our hypothesis, we also demonstrated that the vigilant strategy for non-losses evoked in the penalty group somehow helped them to be more accurate, partially due to the longer distances of the targets. Maybe, this effect is due to the specificity of the given task. The longer time intervals provoke greater error in their subjective estimation, and in this case, the vigilant strategy turned out to be a benefit for this group.

Our results demonstrate the necessity to pay attention to task specificity, especially with regard to time estimations included in that task. Although every action we do has temporal characteristics and the timing of brief intervals is frequently linked with motor control, we should shed light on the problem of motor task components that are either changed or deteriorated within a choking situation. 


\section{References}

Allakhverdov, V. M. (2000). Soznanie kak paradoks. Eksperimental'naya psikhologika [Consciousness as a paradox. Experimental psychologics] (Vol. 1). Saint Petersburg: DNK. (in Russian)

Ariely, D., Gneezy, U., Loewenstein, G., \& Mazar, N. (2009). Large stakes and big mistakes. The Reviere of Economic Studies, 76(2), 451-469. doi:10.1111/j.1467-937X.2009.00534.x

Baumeister, R. F. (1984). Choking under pressure: self-consciousness and paradoxical effects of incentives on skillful performance. Journal of Personality and Social Psychology, 46(3), 610-620. doi:10.1037/0022-3514.46.3.610

Beilock, S. L., \& Carr, T. H. (2001). On the fragility of skilled performance: What governs choking under pressure? Journal of Experimental Psychology: General, 130(4), 701-725. doi:10.1037/00963445.130.4.701

Beilock, S. L., Carr, T. H., MacMahon, C., \& Starkes, J. L. (2002). When paying attention becomes counterproductive: impact of divided versus skill-focused attention on novice and experienced performance of sensorimotor skills. Journal of Experimental Psychology: Applied, 8(1), 6-16. doi:10.1037/1076-898X.8.1.6

Bernstein, N. A. (1966). Ocherki po phiziologii dvizhenii i phiziologii aktivnosti [Essays on the physiology of movements and physiology of activity]. Moscow: Meditsina. (in Russian).

Cohen-Zada, D., Krumer, A., Rosenboim, M., \& Shapir, O. M. (2017). Choking under pressure and gender: Evidence from professional tennis. Journal of Economic Psychology, 61, 176-190. doi:10.1016/j.joep.2017.04.005

De Paola, M., \& Scoppa, V. (2017). Gender differences in reaction to psychological pressure: evidence from tennis players. European Journal of Work and Organizational Psychology, 26(3), 444-456. doi:10.1080/1359432X.2017.1307178

Eysenck, M. W., \& Calvo, M. G. (1992). Anxiety and performance: The processing efficiency theory. Cognition and Emotion, 6(6), 409-434. doi:10.1080/02699939208409696

Fitts, P. M., \& Posner, M. I. (1967). Human performance. Belmont, CA: Brooks/Cole.

Gershkovich, V. A., Moroshkina, N. V., Allakhverdov, V. M., Ivanchei, I. I., Morozov, M. I., Karpinskaya, V. U., ... Volkov, D. N. (2013). Vozniknovenie povtoryauschikhsya oshibok v protsesse sensomotornogo naucheniya i sposobi ikh korrektsii [Appearance of repeated mistakes in the process of sensorimotor learning and ways of their correction]. Vestnik Sankt-Peterburgskogo Universiteta. Seria 16. Psikhologiya. Pedagogika [Bulletin of St Petersburg University. Series 16. Psychology. Pedagogy ], 3, 43-54. (in Russian)

Gershkovich, V., Moroshkina, N., Kulieva, A., \& Nasledov, A. (2019). Measure of chronic regulatory focus: Adaptation of T. Higgins Regulatory Focus Questionnaire in Russia. Psychology. Journal of Higher School of Economics, 16(2), 318-340. doi:10.17323/1813-8918-2019-2-318-340 (in Russian)

Gershkovich, V., \& Urikh, D. (2017). The "I am losing" effect in a simple sensorimotor task. Psychology. Journal of Higher School of Economics, 14(1), 178-188. doi:10.17323/1813-8918-2017-1-178-188

Gneezy, U., Niederle, M., \& Rustichini, A. (2003). Performance in competitive environments: Gender differences. The Quarterly Journal of Economics, 118(3), 1049-1074. doi:10.1162/00335530360698496

Herai, T., \& Mogi, K. (2014). Perception of temporal duration affected by automatic and controlled movements. Conscious and Cognition, 29, 23-35. doi:10.1016/j.concog.2014.07.012 
Higgins, E. T. (1997). Beyond pleasure and pain. American Psychologist, 52(12), 1280-1300. doi:10.1037/0003-066X.52.12.1280

Higgins, E. T. (1998). Promotion and prevention: Regulatory focus as a motivational principle. Advances in Experimental Social Psychology, 30, 1-46.

Higgins, E. T., Friedman, R. S., Harlow, R. E., Idson, L. C., Ayduk, O. N., \& Taylor, A. (2001). Achievement orientations from subjective histories of success: Promotion pride versus prevention pride. European Journal of Social Psychology, 31, 3-23. doi:10.1002/ejsp.27

Kochetkova, S. V. (2000). Povyshenie sorevnovatelnoi nadezhnosti sportsmenov-strelkov na osnove makro- $i$ mikrovremenny faktorov ee formirovaniya [Improving the competitive reliability of sporting shooters based on macro- and micro-temporal factors of its formation] (Ph.D. dissertation). Kuban State University of Physical Culture, Sport and Tourism, Krasnodar, Russian Federation. (in Russian)

Lewis, P. A., \& Miall, R. C. (2003). Distinct systems for automatic and cognitively controlled time measurement: evidence from neuroimaging. Current Opinion in Neurobiology, 13(2), 250-255. doi:10.1016/S0959-4388(03)00036-9

Malinina, S. V. (2006). Pokazatel nadezhnosti sportsmenov - osnovy sorevnovatelnoj deyatelnosti [The reliability indicator in athletes as the basis of competitive activity]. Nauchno-Teoreticheskii Zhurnal "Uchenye zapiski" [Scientific and Theoretical Journal "Scientific Notes"], 22, 32-37. (in Russian)

Masters, R. S. (1992). Knowledge, knerves and know how: The role of explicit versus implicit knowledge in the breakdown of a complex motor skill under pressure. British Journal of Psychology, 83(3), 343-358. doi:10.1111/j.2044-8295.1992.tb02446.x

Medvedev, V. V., Rodionov, A. V., \& Khudadov, N. A. (1973). O psikhicheskikh sostoyaniyakh v sportivnoy deyatelnost [About mental conditions in sports]. In P. A. Rudik, V. V. Medvedev, \& A. V. Rodionov (Eds.), Psikhologiya i sozremennyi sport [Psychology and Modern Sport] (pp. 217 241). Moscow: Fizkul'tura i sport. (in Russian)

Moroshkina, N. V., Gershkovich, V. A., Ivanchei, I. I., \& Morozov, M. I. (2012). Vliyanie structury voznagrazhdeniya na vypolnenie sensomotornykh navykov [Influence of the reward structure on the performance of sensorimotor skills]. In V. A. Barabanshchikov (Ed.), Eksperimentalniy metod v strukture psikhologicheskogo znaniya [The experimental method in the structure of psychological knowledge] (pp. 239-244). Moscow: Institute of Psychology of the RAS. (in Russian)

Plakhtienko, V. A., \& Bludov, Yu. M. (1983). Nadezhnost'v sporte [Reliability in sports]. Moscow: Fizkul'tura i sport. (in Russian)

Safonov, V. K. (2018). Cognitive dissonance in sports motivation (Practical experience at high performance sports). Peterburgskij Psihologičeskij Žurnal, 23, 122-135. (in Russian)

Shah, J., \& Higgins, E. T. (2001). Regulatory concerns and appraisal efficiency: The general impact of promotion and prevention. Journal of Personality and Social Psychology, 80(5), 693-705. doi:10.1037/0022-3514.80.5.693

Tversky, A., \& Kahneman, D. (1979). Prospect theory: An analysis of decision under risk. Econometrica, $47(2), 263-291$.

Unkelbach, C., Plessner, H., \& Memmert, D. (2009). "Fit” in sports. In J. P. Forgas, R. F. Baumeister, \& D. M. Tice (Eds.), The Sydney symposium of social psychology: Vol. 11. Self-regulation and athletic performances (pp. 93-105). Psychology Press.

Vainstein, L. M. (1981). Psikhologiya v pulevoi strelbe [Psychology in shooting sports]. Moscow: DOSAAF. (in Russian) 
Wegner, D. M. (1994). Ironic processes of mental control. Psychological Review, 101(1), 34-52. doi:10.1037/0033-295X.101.1.34

Wilson, M. (2008). From processing efficiency to attentional control: A mechanistic account of the anxiety-performance relationship. International Reviezo of Sport and Exercise Psychology, 1, $184-202$. doi:10.1080/17509840802400787

Valeriia A. Gershkovich - Associate Professor, Department of the Problems of Convergence in Natural Sciences and Humanities, Saint Petersburg State University, PhD in Psychology.

Research Area: cognitive psychology, cognitive control in memory and learning tasks, choking under pressure, achievement motivation, memory illusions.

E-mail: valeria.gerhskovich@gmail.com

Nadezhda V. Moroshkina - Senior Researcher, Laboratory of Cognitive Studies, Saint Petersburg State University, PhD in Psychology.

Research Area: cognitive psychology, implicit learning and implicit memory, consciousness and cognitive unconsciousness, frame effects, achievement motivation.

E-mail: moroshkina.n@gmail.com

Almara K. Kulieva - PhD Student, Department of General Psychology, Saint Petersburg State University.

Research Area: cognitive psychology, consciousness, psychology of will, visual illusions.

E-mail: almara.kulieva@gmail.com

\title{
Плохо ли, когда контроля слишком много? Влияние регуляторного фокуса на оценку коротких временнб́х интервалов в ситуации соревновательного давления
}

\author{
В.А. Гершкович ${ }^{a}$ Н.В. Морошкина ${ }^{\text {a }, ~ А . К . ~ К у л и е в а ~}{ }^{\text {a }}$ \\ ${ }^{a}$ Санкт-Петербургский государственный университет, 199034, Россия, Санкт-Петербург, \\ Университетская наб., д. 7/9
}

\section{Резюме}

Срыв навыка под давлением - это феномен, известный в спорте как ошибка в выполнении автоматизированного действия, которая проявляется в условиях повышенных требований к качеству выполнения задачи (Baumeister, 1984). В ряде теорий утверждается, что причиной такого срыва является избыточный контроль, который приводит к деавтоматизации навыка. Согласно нашей гипотезе, избыточный контроль возникает вследствие страха совершить ошибку, поскольку попытка проверить, «не совершаю ли я ошибочное действие», может спровоцировать само ошибочное действие (Allakhverdov, 2000; Wegner, 1994). В работе исследовалось влияние двух факторов: фактора ценности (обычные попытки vs ценные попытки), фактора фрейма задачи (вознаграждение vs штраф). Участники играли в компьютерную игру «Гольф», соревнуясь друг с другом. Для попадания в лунки разной дальности им необходимо было научиться удерживать клавишу «пробел» в течение определенного времени (2, 4, 6, 8 сек). В ходе 
соревнования варьировалась ценность лунок, при этом одна группа штрафовалась за промах по ценным лункам, тогда как другая группа дополнительно поощрялась за попадание по ним. Полученные результаты свидетельствуют в пользу гипотезы избыточного контроля. Обнаружен эффект «срыва навыка под давлением» при выполнении ударов по ближним лункам (2 сек): по ценным лункам испытуемые обеих групп промахивались чаще, чем по обычным. Обнаружено влияние фрейма задачи (вознаграждение vs штраф) на время подготовки к выполнению ударов: группа «штраф» готовилась дольше. Также показано, что чем больше времени требовалось на подготовку к удару, тем более вероятно было последующее совершение ошибки.

Ключевые слова: соревновательное давление, срыв навыка под давлением, избыточный контроль, оценка временны́х интервалов, регуляторный фокус, фрейм задачи, штраф, вознаграждение, ошибка.

Гершкович Валерия Александровна - доцент, кафедра проблем конвергенции естественных и гуманитарных наук, Санкт-Петербургский государственный университет, кандидат психологических наук.

Сфера научных интересов: когнитивная психология, когнитивный контроль, научение, соревновательный стресс, мотивация достижения, иллюзии памяти.

Контакты: valeria.gerhskovich@gmail.com

Морошкина Надежда Владимировна - старший научный сотрудник, лаборатория когнитивных исследований, Санкт-Петербургский государственный университет, кандидат психологических наук.

Сфера научных интересов: когнитивная психология, имплицитное научение и память, сознание и когнитивное бессознательное, эффекты фрейма, мотивация достижения.

Контакты : moroshkina.n@gmail.com

Кулиева Алмара Кудрат кызы - аспирант, кафедра общей психологии, Санкт-Петербургский государственный университет.

Сфера научных интересов: когнитивная психология, психология сознания, психология воли, зрительные иллюзии.

Контакты : almara.kulieva@gmail.com 